\title{
Resistant Hypokalemia Improving After Radical Nephrectomy: A Case Report
}

\section{Olgu Sunumu: Radikal Nefrektomi Sonrası Düzelen Dirençli Hipokalemi}

\author{
(D) Mustafa Dinçkal, (D) Fuat Kızılay, (D) Mustafa Serdar Kalemci, (D) Adnan Şimşir \\ Ege University Faculty of Medicine, Department of Urology, İzmir, Turkiye
}

\begin{abstract}
Paraneoplastic syndromes are systemic disorders developing in response to any neoplasm and may have various clinical symptoms depending on the affected organ system. Hypercalcemia, one of the renal cell carcinoma (RCC) - Related Paraneoplastic syndromes, occurs in approximately 20\% of patients with RCC. Although clinical conditions such as paraneoplastic hypercalcemia and polycythemia are more common complications of $\mathrm{RCC}$, there are rarer paraneoplastic syndromes such as hepatic dysfunction, galactorrhea and Cushing's syndrome. It has been reported that RCC accounted for $2 \%$ of all cancers responsible for for Cushing's syndrome and the symptoms associated with Cushing's syndrome remited after surgical treatment. In our patient, although serum isolated adrenocorticotropic hormone, aldosterone and cortisol levels were normal, there was treatment resistant hypokalemic metabolic alkalosis and this was not related to Cushing's syndrome. Complete normalization of the clinical picture and laboratory values after radical nephrectomy suggests that hypokalemic metabolic alkalosis may be a Paraneoplastic syndrome associated with RCC. Keywords: Carcinoma, Adenocarcinoma, Hypopotasemia, Hypokalemia, Cushing's syndrome, Nephrectomy, Radical Nephrectomy, Oncology, Urooncology

\section{Öz}

Paraneoplastik sendromlar, herhangi bir neoplazmaya yanıt olarak gelişen sistemik bozukluklardır ve etkilenen organ sistemine bağlı olarak çeşitli klinik semptomlara neden olabilir. Böbrek hücreli kanser (RCC) ile ilişkili Paraneoplastik sendromlardan biri olan hiperkalsemi, RCC hastalarının yaklaşık \%20'sinde görülür. Paraneoplastik hiperkalsemi ve polisitemi gibi klinik durumlar RCC'nin daha sık görülen komplikasyonları olmasına rağmen, hepatik disfonksiyon, galaktore ve Cushing sendromu gibi daha nadir Paraneoplastik sendromlar da vardır. Paraneoplastik Cushing sendromu, RCC'nin Cushing sendromundan sorumlu tüm kanserlerin \%2'sini oluşturduğunu ve Cushing sendromuyla ilişkili semptomların cerrahi eksizyondan sonra giderildiğini bildirmiştir (6). Hastamızda serum izole adrenokortikotropik hormon, aldosteron ve kortizol düzeyleri normal olmasına rağmen tedaviye dirençli hipokalemik metabolik alkaloz vardı ve bu Cushing sendromu ile ilişkili değildi. Radikal nefrektomi sonrası klinik tablonun ve laboratuvar değerlerinin tamamen normale dönmesi, hipokalemik metabolik alkolozun RCC ile ilişkili bir Paraneoplastik sendrom olabileceğini düşündürmektedir.
\end{abstract}

Anahtar Kelimeler: Karsinom, Adenokarsinom, Hipopotasemi, Hipokalemi, Cushing sendromu, Nefrektomi, Radikal Nefrektomi, Onkoloji, Üroonkoloji

\section{Introduction}

Paraneoplastic syndromes are systemic pathologies that may occur due to any malignancy and affect various organ systems (1). The classical triad of palpable mass, flank pain and hematuria is seen in $15 \%$ of patients with renal cell carcinoma (RCC), whereas the probability of developing RCCrelated Paraneoplastic syndrome is $40 \%$ (1). The most common paraneoplastic complication of RCC is hypercalcemia (2).
Other RCC-related Paraneoplastic syndromes include Cushing's syndrome (1). Symptoms of Cushing's syndrome may include nausea, vomiting, hypokalemia and metabolic alkalosis (3). In our case, nausea, vomiting, hypokalemia and metabolic alkalosis suggested Cushing's syndrome which may develop due to RCC. However, the patient's findings were not consistent with Cushing's syndrome. No similar case has been reported in the literature previously.

Correspondence: Mustafa Dinçkal MD, Ege University Faculty of Medicine, Department of Urology, İzmir, Turkiye Phone: +90 2323902500 E-mail: drmustafadinckal@gmail.com ORCID-ID: orcid.org/0000-0003-4905-1602 Received: 24.10 .2019 Accepted: 24.11 .2019

Cite this article as: Dinçkal M, Kızılay F, Kalemci MS, Şimşir A. Resistant Hypokalemia Improving After Radical Nephrectomy: A Case Report. 2020;7(1):58-60.

๑Copyright 2020 by the Association of Urological Surgery / Journal of Urological Surgery published by Galenos Publishing House. 


\section{Case Report}

A 53-year-old male patient presented with the complaints of weakness, abdominal pain, nausea and vomiting. These complaints were present for about 1 month and increased gradually in recent days. Physical examination revealed no pathological findings other than central obesity. He had a history of hypertension. Abdominal ultrasonography revealed a $10 \mathrm{~cm}$ mass in the left kidney. Whole body computed tomography revealed an exophytic solid mass of $14 \mathrm{~cm}$ in length and approximately $10 \times 9.5 \mathrm{~cm}$ in transverse dimensions in the lower pole of the left kidney. There was no evidence of renal vein invasion. No pathological finding and a typical distant metastasis were detected in both adrenal glands (Figure 1, 2).

Written informed consent was obtained from the patient and left radical nephrectomy was planned and preoperative preparations were started. The results of blood analysis were as follows: potassium - $2.5 \mathrm{mEq} / \mathrm{L}$ (reference range: $3.5-5 \mathrm{mEq} / \mathrm{L}$ ), creatinine - $1.7 \mathrm{mg} / \mathrm{dL}(0.7-1.3 \mathrm{mg} / \mathrm{dL})$, sodium - $133 \mathrm{mEq} / \mathrm{L}(136-$ $145 \mathrm{mEq} / \mathrm{L})$, hemoglobin $-9.8 \mathrm{~g} / \mathrm{dL}(13.1-17.2 \mathrm{~g} / \mathrm{dL})$, hematocrit 27.9\% (39-50\%), and urine $\mathrm{pH}-6$. Nephrology consultation was obtained and potassium chloride (KCL) replacement (infusion in

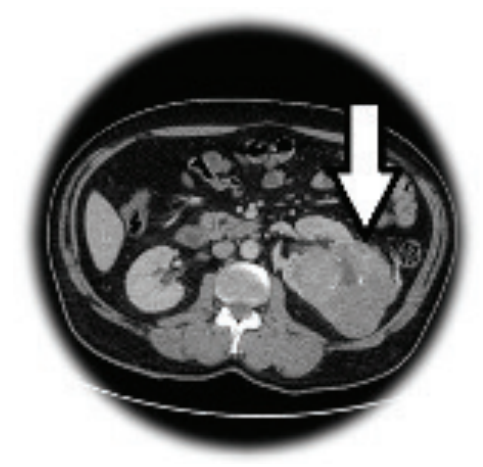

Figure 1. The appearance of the mass on computed tomography

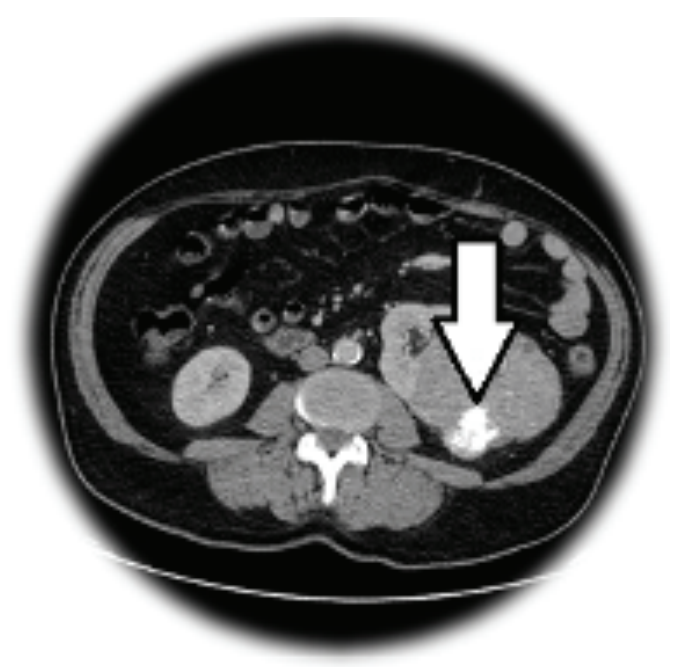

Figure 2. The appearance of calcification in the mass on computed tomography
1000 cc saline at 60 meq and 10 hours) was initiated according to the recommendations. Nausea and vomiting were controlled by antiemetic treatment during the hospitalization period. However, despite repeated KCL replacement several times, the patient's potassium level did not increase significantly. The values were as follows: $\mathrm{PH}$ - 7.55, HCO3 - $37.4 \mathrm{mmol} / \mathrm{L}(22-26)$, and PCO2 - $43.2 \mathrm{mmHg}$ (35-45) potassium - $2.5 \mathrm{mEq} / \mathrm{L}$ (3.5-5).

Endocrinology consultation was requested according to the recommendations of the nephrology clinic. The tests requested by endocrinologists revealed the followings: total cholesterol - $139 \mathrm{mg} / \mathrm{dL}$ (<200), triglyceride - 186 mg/dL (<150), high density lipoprotein cholesterol: $22 \mathrm{mg} / \mathrm{dL}(>55), \mathrm{LDL}$ cholesterol (calculated using the Friedewald equation) - $80 \mathrm{mg} / \mathrm{dL}(<130)$, isolated adrenocorticotropic hormone (ACTH) (morning) $42.6 \mathrm{pg} / \mathrm{mL}(<46), \mathrm{TSH}$ - $1.9 \mu \mathrm{lU} / \mathrm{mL}$ (0.27-4.2), FT4 - $1.47 \mathrm{ng} /$ $\mathrm{dL}$ (0.93-1.7), cortisol (morning) - $13.11 \mu \mathrm{g} / \mathrm{dL}$ (4.82-19.5), 17- $\mathrm{OH}$ progesterone - $79 \mathrm{ng} / \mathrm{dL}$ (20-250), and aldosterone $5.0 \mathrm{ng} / \mathrm{dL}$ (2-18). Acetazolamide tablets were started by the nephrology clinic due to alkalosis, and he was operated under KCL replacement therapy (infusion in 1000 cc saline for 60 meq and 10 hours) and left radical nephrectomy was performed.

The level of potassium was $4.2 \mathrm{mEq} / \mathrm{L}$ (3.5-5) and $\mathrm{pH}$ was 7.39 on the first postoperative day, and potassium was $4.4 \mathrm{mEq} / \mathrm{L}$ (3.5-5) and $\mathrm{pH}$ was 7.40 at the first postoperative month. Histopathological investigation of the surgical specimen revealed chromophobe RCC and negative surgical margins.

\section{Discussion}

$\mathrm{RCC}$ is the 6th most common cancer in males and 10th in females (4). The incidence of RCC is increasing due to the widespread use of abdominal imaging especially for musculoskeletal complaints or gastrointestinal complaints (5).

Although clinical conditions such as paraneoplastic hypercalcemia and polycythemia common in RCC, there are less common Paraneoplastic syndromes such as hepatic dysfunction, galactorrhea and Cushing's syndrome (1). Riggs and Sprague (6) reported that RCC accounted for $2 \%$ of all cancers responsible for Cushing's syndrome and the symptoms associated with Cushing's syndrome remitted after surgical treatment. RCCinduced Cushing's syndrome is thought to be due to ectopic ACTH secretion by tumor cells (6). In patients undergoing radical or partial nephrectomy, Cushing's syndrome can be treated by eliminating ectopic ACTH-producing tumor cells. Elevated levels of ACTH in the postoperative period may be associated with disease recurrence or progression (7).

Naert et al. (8) reported a case of necrotizing myopathy in a patient with a right renal mass in whom a remission of myopathy was observed after radical nephrectomy. 
Hypokalemic metabolic alkalosis may occur in patients with Cushing's syndrome (9). In our patient, although serum ACTH, aldosterone and cortisol levels were normal, there was resistant hypokalemic metabolic alkalosis and this was not related with Cushing's syndrome. The complete normalization of the clinical picture and laboratory values after radical nephrectomy suggests that hypokalemic metabolic alkalosis may be a Paraneoplastic syndrome associated with RCC.

\section{Ethics}

Informed Consent: Written informed consent was obtained from the patient.

Peer-review: Externally peer-reviewed.

\section{Authorship Contributions}

Concept: F.K., M.S.K., M.D., Design: F.K., M.S.K., M.D., Data Collection and/or Processing: M.D., Analysis and/or Interpretation: A.Ş., F.K., M.S.K., M.D., Literature Research: M.D., Writing: M.D.

Conflict of Interest: No conflict of interest was declared by the authors.
Financial Disclosure: The authors declared that this study received no financial support.

\section{References}

1. Palapattu GS, Kristo B, Rajfer J. Paraneoplastic Syndromes in Urologic Malignancy: The Many Faces of Renal Cell Carcinoma. Rev Urol 2002;4(4):163-170.

2. Bajorin DF. Goldman-Cecil Medicine. 2016.

3. Mark E. Molitch. Goldman-Cecil Medicine. Twenty-Fif. 2016.

4. Siegel RL, Miller KD, Jemal A. Cancer Statistics, 2017. CA Cancer J Clin 2017;67:7-30.

5. Wu X, Shu X. Epidemiology of renal cell carcinoma. Ren Cell Carcinoma Mol Featur Treat Updat 2017;75:1-18.

6. Riggs BL Jr, Sprague RG. Association of Cushing's syndrome and Neoplastic Disease. Arch Intern Med 1961;108:841-9.

7. Bartuska DG. Humor manifestations of neoplasms. Semin Oncol 1975;2:405-

8. Naert E, De Bleecker JL, Lumen $\mathrm{N}$, Rottey $\mathrm{S}$. Necrotizing myopathy as a paraneoplastic syndrome associated with renal cell carcinoma. Acta Clin Belg 2015;70:61-4.

9. Christy NP, Laragh JH. Pathogenesis of Hypokalemic Alkalosis in Cushing's syndrome. N Engl J Med 1961;265:1083-8. 